daily. The asthma of more than half of these patients seems either to have been very mild or very well controlled by prednisone, for 24 children never needed their inhaler when on placebo and 28 when on cromoglycate, this difference being negligible. Of the 17 children on steroids, three were able to reduce them on cromoglycate from 5 to $2.5 \mathrm{mg}$. and one was able to reduce them from 15 to $10 \mathrm{mg}$., again a negligible difference. If asthmatic patients who are almost well are used in such a trial much difference in their state cannot be expected, even if they were to improve. Moran et al. (1968) treated 21 allergic patients, of whom 11 improved. But most of these patients had little or no sputum. This suggests that their asthma was very mild and intermittent. We know hardly any patients with chronic asthma without cough and sputum.

Most of these investigations seem to have been done with the coarse cromoglycate powder which will hardly have reached regions lower than the largest bronchi. Moreover, they concern patients without a stable chronic asthma who are not suitable for trials of this kind. It is not surprising that the authors report improvement of about $50 \%$, the same percentage which has been reported with many other so-called asthma remedies which have long been forgotten. In these circumstances we reluctantly agree with the unenthusiastic attitude of Kidner et al. (1968), who found an improvement in $38 \%$ of their 28 patients but say that the difference between cromoglycate and placebo was seldom striking. We can also agree with Grant $(1968,1969)$, who did not see a statistically significant degree of improvement.
Such an improvement can hardly be expected if our protection experiments are correct. On the other hand, we are convinced that cromoglycate can protect or improve individual patients, perhaps one in ten or one in five. This small chance of improvement is reminiscent of the transitory role of khellin, from which disodium cromoglycate seems to be derived, played some years ago in the treatment of asthma. At that time many observers thought that khellin was effective, but only in a few individual cases, not enough to make it a generally useful treatment. Nevertheless, we agree with previous observers that cromoglycate may prove to be an interesting and valuable research tool.

\section{REFERENCES}

Altounyan, R. E. C. (1965). Summary of information on FPL 670. Fisons Ltd.

Grant, I. W. B. (1968). Lancet, 2, 282.

Grant, I. W. B. (1969). British Medical fournal, 1, 842.

Herxheimer, H. (1949). Fournal of Physiology (London), 109, 4P.

Herxheimer, H. (1963). Acta Allergologica (Kфbenhavn), 18, 1.

Herxheimer, H., and Stresemann, E. (1961). Naunyn-Schmiedeberg's Archiv für experimentelle Pathologie und Pharmakologie, 241, 225. Howell, J. B. L., and Altounyan, R. E. C. (1967). Lancet, 2, 539.

Kennedy, M. C. S. (1967). Lancet, 2, 838.

Kidner, P. H., Meisner, P., Pride, N. B., and Pearson, R. S. B. (1968). Lancet, 2, 655.

Moran, F., Bankier, J. D. H., and Boyd, G. (1968). Lancet, 2, 137. Pepys, J., Hargreave, F. E., Chan, M., and McCarthy, D. S. (1968).
Lancet, 2, 134 .

Smith, J. M., and Devey, G. F. (1968). British Medical fournal, 2, 340.

\title{
Arterial Pressures in Rural and Urban Populations in Nigeria
}

\author{
O. O. AKINKUGBE,* M.D., D.PHIL., F.R.C.P.ED.; O. A. OJO, $\dagger$ M.D., M.A.O., M.R.C.O.G.
}

\begin{abstract}
Summary : Surveys of arterial pressure carried out in $N$ rural and urban communities in Western Nigeria showed a steady rise in systolic values with age, this trend being less marked with diastolic pressures. Blood pressure levels were similar in women from rural and urban areas, but seemed much higher in urban than in rural men. The incidence of proteinuria was lowest in the female urban group. In general, the incidence of proteinuria or glycosuria was low and did not appear to be related to the blood pressure.
\end{abstract}

\section{Introduction}

There is a good deal of evidence to show that the arterial pressure in Negro populations in the United States and in the West Indies is higher than in white populations (Adams, 1932; Gover, 1948 ; Johnson and Remington, 1961). As the ancestors of Negroes in these areas came from the west coast of Africa it seemed worth while to examine data from indigenous populations of West Africa for comparison, so that the influence on the blood pressure of different environments and socio-economic and other factors in Negroes might be more clearly understood.

* Profess $\cdot r$ of Medicine.

† Professor of Obstetrics and Gynaecology.

University of Ibadan, Nigeria.

\section{Methods}

Two populations in Western Nigeria were defined-one rural and the other urban-and the study was carried out in two stages.

Rural Study.-Eruwa, a village conglomeration with a population of 22,000 in the Ibarapa District of Western Nigeria, lies in rolling savannah country just outside the belt of tropical rain forest. The vast majority of its inhabitants are illiterate, the sources of livelihood being farming. Two factors account for the selection of this village for study: firstly, the inhabitants are already accustomed to medical surveys, and, secondly, the population is stable and ethnically homogeneous, being composed almost entirely of the Yoruba tribe. The village was divided into four wards and each ward into an enumeration area comprising 25 to 30 houses, the number of people in an area ranging from 200 to 900 . Each enumeration area was grouped into units according to size, a unit consisting of 200 inhabitants. Thus there were 103 units, of which 20 were randomly selected. Altogether 3,602 subjects aged 5 to over 70 years were examined (1,696 males and 1,906 females), giving a response rate of about $90 \%$.

Urban Study.-To a large extent Ibadan is a city-village, with a million inhabitants (Lloyd, 1967). Its core is peopled by farmers, small traders, and artisans living in large compounds organized on principles of common descent. Those 
who are full-time farmers live for much of the year in one of the several hundred hamlets on the outskirts of the city and commute regularly between compound and farm. This agricultural group does not differ in any important respects from the rural community at Eruwa. There is, however, a growing body of craftsmen, traders, clerks, and factory workers who more truly represent the urban community. The new educated African élite comprise senior civil servants, university teachers, lawyers, doctors, and top business executives. The urban study is concerned not with the indigent or small élite group but with the middle group, who constitute the low-income working-class population. All 821 workers (566 males and 255 females) in a local tobacco factory and a main shopping centre in the city were examined.

In both the rural ard the urban surveys blood pressure readings were taken with a standard mercury manometer with a cuff size of 13 by $25 \mathrm{~cm}$. after the subjects had been seated for some minutes with the arm extended on a table. The diastolic pressure was taken as that at which muffling of sounds occurred (diastolic 4), and readings were then recorded at the nearest $5-\mathrm{mm}$. or $10-\mathrm{mm}$. gradation below the observed figure. Measurements were made between 9 a.m. and 7 p.m. Freshly voided urine samples were examined for protein (Albustix) and sugar (Clinistix).

\section{Results}

The frequency distributions of systolic and diastolic pressures in both sexes are shown in Fig. 1 (rural) and Fig. 2 (urban) in

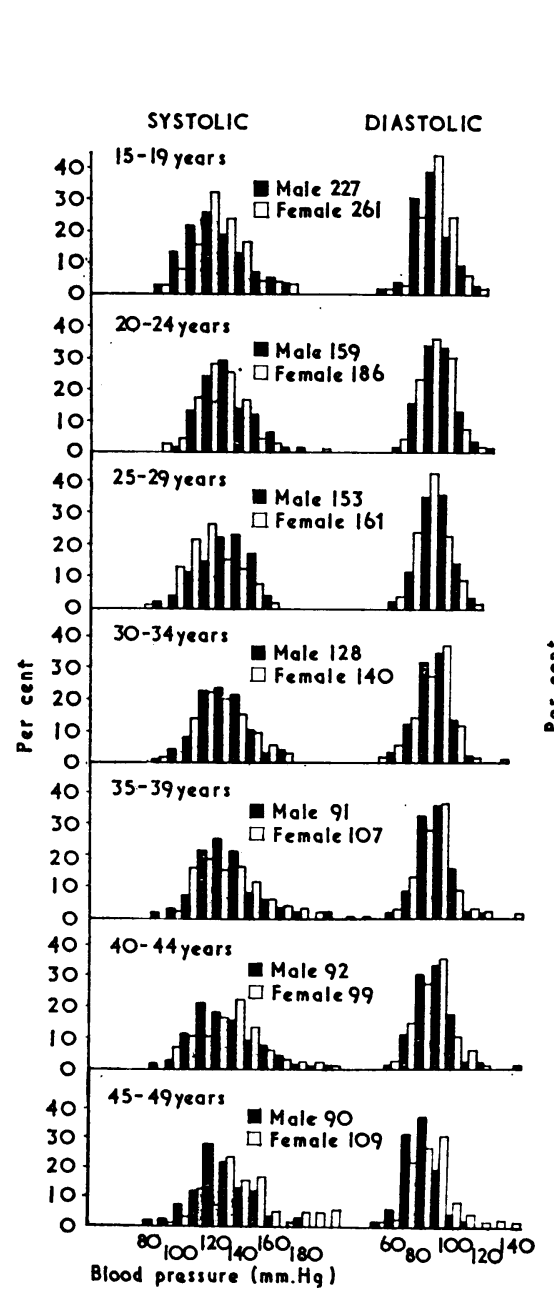

Fig. 1

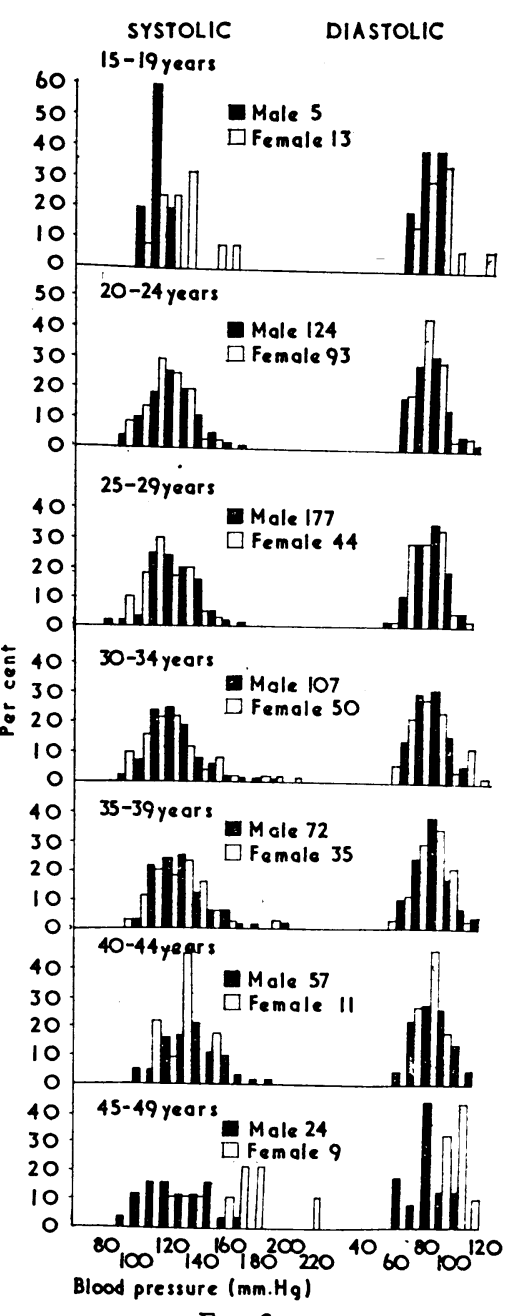

Fig. 2
FIG. 1.-Rural survey, Eruwa, 1967. Frequency distribution of blood pressures. Male and female. FIG. 2.-Urban survey, Ibadan, 1968. Frequency distribution of blood pressures. Male and female. five-year groups between 15 and 50 years of age. It is seen that in the two populations the systolic blood pressure advances with age in both males and females. It can also be observed in the two groups that the systolic curves appeared positively skewed with increasing age. In neither population did diastolic pressures seem conspicuously to increase with age as did the systolic.

TABle I.-Mean Systolic and Diastolic Pressures in Rural and Urban Populations Nigeria (1967-8)

\begin{tabular}{|c|c|c|c|c|c|c|c|c|c|c|}
\hline \multirow{3}{*}{$\underset{\text { (years) }}{\text { Age }}$} & \multicolumn{5}{|c|}{ Rural Population } & \multicolumn{5}{|c|}{ Urban Population } \\
\hline & \multirow{2}{*}{ No. } & \multicolumn{2}{|c|}{ Systolic } & \multicolumn{2}{|c|}{ Diastolic } & \multirow{2}{*}{ No. } & \multicolumn{2}{|c|}{ Systolic } & \multicolumn{2}{|c|}{ Diastolic } \\
\hline & & Mean & S.D. & Mean & S.D. & & Mean & S.D. & Mean & S.D. \\
\hline \multicolumn{11}{|c|}{ Male } \\
\hline $\begin{array}{l}15-19 \\
20-24 \\
25-29 \\
30-34 \\
35-39 \\
40-44 \\
45-49 \\
50-54\end{array}$ & $\begin{array}{r}238 \\
132 \\
169 \\
128 \\
91 \\
91 \\
90 \\
86\end{array}$ & $\begin{array}{l}116.1 \\
122.4 \\
122.8 \\
121.1 \\
123.2 \\
124.6 \\
126.8 \\
131.5\end{array}$ & $\begin{array}{l}19 \cdot 4 \\
16 \cdot 2 \\
16 \cdot 6 \\
16 \cdot 0 \\
17 \cdot 9 \\
20 \cdot 4 \\
17 \cdot 8 \\
18.5\end{array}$ & $\begin{array}{l}71 \cdot 4 \\
75 \cdot 9 \\
77 \cdot 0 \\
75 \cdot 3 \\
77 \cdot 4 \\
77 \cdot 0 \\
77 \cdot 8 \\
80 \cdot 1\end{array}$ & $\begin{array}{l}11 \cdot 6 \\
10.0 \\
10 \cdot 4 \\
11 \cdot 3 \\
10 \cdot 2 \\
12.5 \\
12 \cdot 3 \\
11 \cdot 1\end{array}$ & $\begin{array}{r}5 \\
120 \\
174 \\
108 \\
73 \\
58 \\
24 \\
26\end{array}$ & $\begin{array}{l}114.0 \\
123.5 \\
125.0 \\
125.5 \\
130.5 \\
137.5 \\
132.5 \\
146.2\end{array}$ & $\begin{array}{l}10 \cdot 7 \\
16.4 \\
15 \cdot 3 \\
19 \cdot 4 \\
19.0 \\
19 \cdot 3 \\
23.6 \\
29.5\end{array}$ & $\begin{array}{l}73 \cdot 0 \\
77 \cdot 3 \\
78 \cdot 2 \\
77 \cdot 7 \\
80 \cdot 1 \\
84 \cdot 3 \\
80 \cdot 2 \\
90 \cdot 4\end{array}$ & $\begin{array}{r}6.0 \\
11.1 \\
10.5 \\
11.0 \\
11.9 \\
12.9 \\
12.2 \\
15.8\end{array}$ \\
\hline \multicolumn{11}{|c|}{ Female } \\
\hline $\begin{array}{l}15-19 \\
20-24 \\
25-29 \\
30-34 \\
35-39 \\
40-44 \\
45-49 \\
50-54\end{array}$ & $\begin{array}{r}261 \\
212 \\
165 \\
140 \\
107 \\
99 \\
112 \\
98\end{array}$ & $\begin{array}{l}115.0 \\
116.5 \\
113.6 \\
120.9 \\
126.6 \\
128.6 \\
142.3 \\
140.6\end{array}$ & $\begin{array}{l}14 \cdot 1 \\
14 \cdot 5 \\
16 \cdot 9 \\
18 \cdot 4 \\
24 \cdot 3 \\
24 \cdot 4 \\
27 \cdot 8 \\
26 \cdot 3\end{array}$ & $\begin{array}{l}72 \cdot 1 \\
73 \cdot 4 \\
71 \cdot 8 \\
74.9 \\
77 \cdot 1 \\
76.6 \\
85.6 \\
84.3\end{array}$ & $\begin{array}{r}9 \cdot 2 \\
10 \cdot 2 \\
10 \cdot 2 \\
12 \cdot 4 \\
14 \cdot 3 \\
14 \cdot 1 \\
14 \cdot 5 \\
13 \cdot 8\end{array}$ & $\begin{array}{r}13 \\
96 \\
38 \\
48 \\
32 \\
10 \\
9 \\
3\end{array}$ & $\begin{array}{l}125.8 \\
117.7 \\
121.8 \\
120.9 \\
126.1 \\
130.0 \\
160.6 \\
143.3\end{array}$ & $\begin{array}{r}15.0 \\
15.6 \\
21.2 \\
21.6 \\
19.8 \\
12.8 \\
30.0 \\
6.2\end{array}$ & $\begin{array}{l}78 \cdot 5 \\
72 \cdot 2 \\
73 \cdot 0 \\
75 \cdot 4 \\
77 \cdot 7 \\
81 \cdot 0 \\
95 \cdot 0 \\
88 \cdot 3\end{array}$ & $\begin{array}{r}11.2 \\
9.8 \\
10.3 \\
14.0 \\
10.7 \\
6.6 \\
8.8 \\
2.4\end{array}$ \\
\hline
\end{tabular}

The mean values, with standard deviations, of the arterial pressures are given in Table I. It can be seen that in both males and females the mean systolic and diastolic pressures in the urban group appeared consistently higher than in the rural group. For the males of both populations the highest mean figure occurred in those aged 50-54 and for the females in those aged 45-49.

Urinary Findings.-The results of urine examination for proteinuria in the rural and urban populations, each undertaken on two separate occasions at six-week interval, are shown in Table II. In the rural study 36 out of 193 males $(17.7 \%)$ and 46 out of 260 females $(16.7 \%)$ had persistent proteinuria. In the urban group 55 males out of $496(11 \cdot 2 \%)$ and 19 females out of $229(6.4 \%)$ had proteinuria.

Only one individual in the rural survey (a woman aged 27) and two subjects in the urban population sample (a man aged 41 and a woman aged 46) had evidence of glycosuria. None of these three subjects had either hypertension or proteinuria.

\section{Discussion}

From these findings it is evident that the casual systolic and diastolic blood pressures of indigenous rural and urban populations in West Africa differ in no important respects from those of Negro populations in the West Indies (Miall et al., 1962). The mean blood pressures in rural Negro populations in the United States (Comstock, 1957), the Caribbean (Miall et al., 1962), and Nigeria (present series) are shown in Fig. 3. In both males and females the mean systolic and diastolic pressures in United States Negroes appeared slightly higher than in West Indian or West African Negroes. Abrahams et al. (1960) had earlier shown that blood pressures in indigenous West Africans were generally similar to those recorded in white populations in Europe and America (Master et al., 1950 ; Hamilton et al., 1954). 
In the West Indian populations studied by them Miall et al. (1962) had noted that mean arterial pressures were higher in women from the rural than from the urban areas. They could not attribute this difference to excess weight, differences in reaction to the examination, migration, or to a genetic basis. In our West African series urban blood pressures were generally higher than rural values in comparable age groups. Yet the diet, socio-economic status, habitus, and degree of activity of the two groups differed in no striking way. It also seems noteworthy that the blood pressure at all ages was higher in the male urban groups than in the other groups. No definite factor can be said to account for this difference

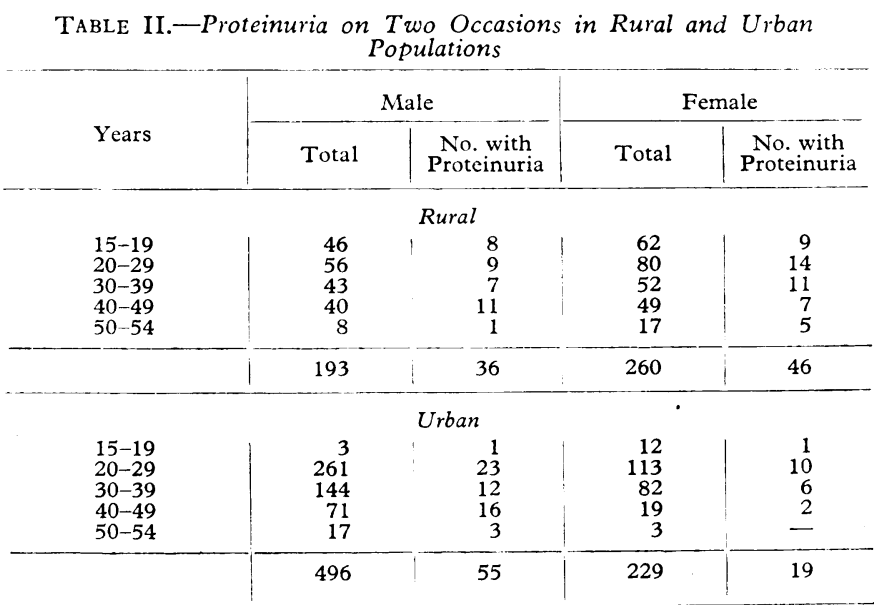

The relatively high incidence of proteinuria in this series may be partly attributed to urinary schistosomiasis, which is known to be endemic in Western Nigeria. The higher incidence of proteinuria in males of both populations may also relate to the prevalence of gonococcal urethral stricture in these groups. As very few of those with proteinuria had hypertension it would seem likely that such hypertension as was found in the rural and urban areas was predominantly essential in origin. This is in general agreement with the findings of Callander (1953) in Nigerian soldiers and army recruits, in whom the incidence of proteinuria was $2.5 \%$.

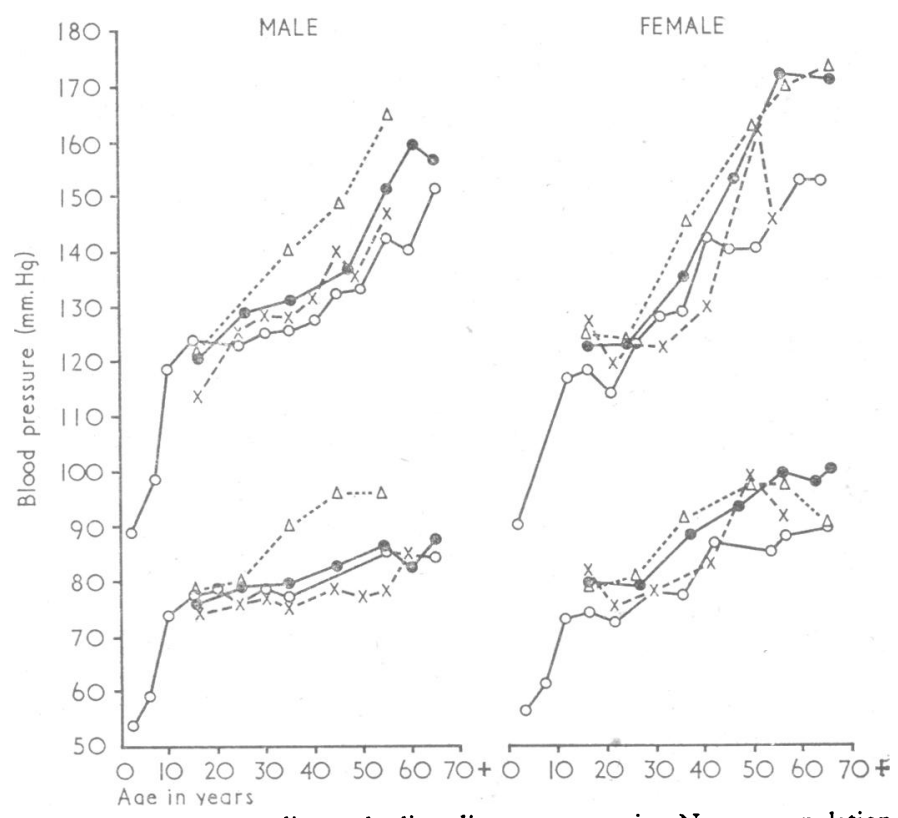

FIG. 3.- Mean systolic and diastolic pressures in Negro population samples. O-O Nigeria rural. Present series, 1967. $\times \ldots-\ldots$ Nigeria urban. Present series, 1968.

\section{REFERENCES}

Abrahams, D. G., Alele, C. A., and Barnard, B. G. (1960). West African Medical fournal, 9, 45 .

Adams, J. M. (1932). American Fournal of the Medical Sciences, 184, 342.

Callander, W. H. (1953). West African Medical fournal, 2, 102.

Comstock, G. W. (1957). American fournal of Hygien

Gover, M. (1948). Public Health Reports, 63, 1083. Hamilton, M., Pickering, G. W., Roberts,

(1954). Clinical Science, 13, 37. D. (1961). fournal of Chronic Diseases, 13, 39.

Lloyd, P. C. (1967). In The City of Ibadan, edited by P. C. Lloyd, A. L. Mabogunje, and B. Awe, p. 3. Cambridge University Press, London.

Master, A. M., Dublin, L. I., and Marks, H. H. (1950). Fournal of the American Medical Association, 143, 1464

Miall, W. E., Kass, E. H., Ling, J., and Stuart, K. L. (1962). British Medical Fournal, 2, 497.

\title{
Phenformin-induced Hypoglycaemia in Normal Subjects*
}

\author{
J. LYNGSøE, † M.D. ; J. TRAP-JENSEN,ł M.D.
}

British Medical fournal, 1969, 2, 224-226

Summary: Study of the effect of phenformin on the $\checkmark$ blood glucose level in normal subjects before and during 70 hours of starvation showed a statistically significant hypoglycaemic effect after $\mathbf{4 0}$ hours of starvation. This effect was not due to increased glucose utilization.

Another finding in this study was a statistically significant decrease in total urinary nitrogen excretion during starvation in subjects given phenformin. These findings show that the hypoglycaemic effect of phenformin in starved normal subjects is due to inhibition of gluconeogenesis.

\section{Introduction}

Phenformin (phenethylbiguanide) is an oral non-sulfonylurea blood-glucose-lowering agent which can act in the absence of insulin. Reduction of hyperglycaemia and glycosuria is well known in patients with diabetes mellitus treated with phenformin. Previous investigations have failed to show any bloodglucose-lowering effect in normal man (Fajans et al., 1960 ;

* This work was supported by a grant from the King Christian $\mathrm{X}$ Foundation.

† Department of Medicine C.

$\mp$ Department of Clinical Physiology.

Bispebjerg Hospital, Copenhagen, Denmark. 